\title{
ע Miesten terveyden edunvalvontaa terveyspolitiikan kentällä: potilaiden perusteluja eturauhassyövän seulonnan tarpeellisuudesta
}

Eturauhassyövän seulonnan hyödyistä ja haitoista on käyty aktiivista keskustelua viime vuosina. Vaikka PSA-testi on laajasti käytössä terveydenhuollossa, väestötason seulontaa ei toistaiseksi suositella, sillä seulonnan haittoja pidetään hyötyjä suurempina. Seulonnan haittoja ovat ylidiagnostiikka ja siitä aiheutuvat ylimääräiset hoidot, jotka voivat heikentää miesten elämänlaatua. Artikkelissa tarkasteltiin paikallista eturauhassyöpää sairastavien miesten näkemyksiä seulonnan tarpeellisuudesta. Tutkimuksen aineisto koostui 28 eturauhassyöpää sairastavan miehen yksilöhaastatteluista. Analyysimenetelmänä käytettiin diskurssianalyysia.

Suurin osa haastateltavista suhtautui myönteisesti väestötason seulontaan ja halusi parantaa miesten pääsyä PSA-mittauksiin. Seulonnan tarpeellisuutta perusteltiin argumenteilla, jotka liittyvät varhaisen diagnostiikan hyötyihin - kuten kustannusten säästymiseen ja kuolleisuuden vähentämiseen - tai miesten oikeuksiin ja sukupuolten tasa-arvoon. Tulostemme perusteella miehet ovat tietoisia seulontaan liittyvistä haitoista, mutta siitä huolimatta he ovat seulonnan käynnistämisen kannalla. Seulonta hahmotettiin miesten terveyden edunvalvontaan liittyvänä asiana.

\section{ASIASANAT: Terveyspolitiikka, miesten terveys, eturauhassyövän seulonta, argumentaatio}

ANNASTIINA HAKULINEN, HANNA OJALA, ILKKA PIETILÄ

\section{YDINASIAT}

- Eturauhassyövän joukkoseulontaa ei suositella, sillä seulonnan haittoja pidetään hyötyjä suurempina.

- Suomessa eturauhassyöpään sairastuneiden miesten, tai väestön laajemmin, suhtautumista seulontaan ei ole juuri tutkittu.

- Eturauhassyöpää sairastavat miehet kannattavat seulontaohjelman käynnistämistä ja laajempaa PSA-testausta.

- Seulonnan negatiivisia vaikutuksia ei huomioida.

- Kysymys seulonnasta hahmotetaan miesten terveyden edunvalvontana.

\section{JOHDANTO}

Eturauhassyövän seulonnasta on käyty aktiivista keskustelua viime vuosina, sillä taudin kansanterveydellinen merkitys on suuri. Eturauhassyöpä on miesten yleisin syöpä ja keuhko- ja henkitorven syövän jälkeen miesten toiseksi yleisin syöpäkuolemien aiheuttaja Suomessa. Eturauhassyöpään sairastuu noin 5000 miestä ja kuolee noin 800900 miestä vuosittain. (1.) Eturauhassyövän seulontaohjelmaa ei ole käynnistetty, sillä tämänhetkisen tutkimustiedon perusteella systemaattisen joukkoseulonnan kriteerit eivät täyty $(2,3)$. Seulonnan edellytyksenä on hyötyjen ja haittojen 
tasapaino sekä riittävä tieto seulonnan yhteiskunnallisista vaikutuksista ja kustannuksista. Seulonnan tulee tuottaa riittävästi terveyttä. (4.) Suomessa toteutettavia syöpäseulontaohjelmia ovat rintasyövän ja kohdunkaulansyövän seulonta naisille, mutta eturauhassyövän seulonnan haittoja pidetään toistaiseksi hyötyjä suurempina (5).

Eturauhassyöpään on olemassa seulontamenetelmä, joka täyttää suuren osan joukkoseulonnan kriteereistä. Oireettomien miesten eturauhassyöpää voidaan seuloa PSA-verinäytteellä (prostataspesifisen antigeenin pitoisuuden mittaus verestä). Jos PSA-pitoisuus on suurentunut, jatkotutkimuksena on eturauhasen tunnustelu, ultraäänitutkimus ja koepalat eturauhasesta. (6.) Syöpäseulonnan tärkein tavoite on vähentää syövästä johtuvaa kuolleisuutta (5), ja PSA-mittaukseen perustuvan seulonnan on havaittu vähentävän eturauhassyöpäkuolleisuutta ja pitkälle edenneiden syöpien ilmaantuvuutta väestötasolla $(7,8)$. Seulonnan seurauksena on mahdollisuus havaita tauti useita vuosia ennen oireiden ilmenemistä, estää syövän leviäminen ja hoitaa varhaisessa vaiheessa todettu syöpä parantavasti.

Seulonnan taloudellisista ja elämänlaatuvaikutuksista ei kuitenkaan tiedetä riittävästi (8). Suomalaisen tutkimuksen (9) mukaan seulontaan osallistuneilla miehillä eturauhassyövän hoitokustannukset ovat pienemmät kuin seulomattomilla. Eturauhassyöpään kuolleiden miesten osalta seulontaan osallistuneilla oli kuitenkin suuremmat terveydenhuollon kokonaiskustannukset kuin seulomattomilla. Väestöseulonnan taloudellisten vaikutusten selvittämiseksi tarvitaan vielä pidemmän seuranta-ajan tietoa. Lyhyellä aikavälillä seulonnan vaikutukset terveyteen liittyvään elämänlaatuun ovat vähäisiä (10).

Seulonnan kääntöpuolena on merkittävä ylidiagnostiikka (11) ja siitä aiheutuvat ylimääräiset hoidot haittoineen. Ylidiagnostiikalla tarkoitetaan sitä, että seulonnassa löytyy syöpiä, jotka eivät ole potilaan elinaikana eteneviä tai tappavia, aiheuta oireita tai vaadi hoitoa (12). Koska merkityksettömiä ja eteneviä kasvaimia ei pystytä riittävän luotettavasti erottelemaan, taudin varhaisessa vaiheessa on vaikeaa ennustaa, ketkä sairastuneista hyötyvät hoidoista (13). Siksi myös vaarattomia varhaisvaiheen syöpiä hoidetaan tarpeettomasti. Tarpeeton hoitaminen on seulonnan suurin ongelma, sillä eturauhassyöpähoitoihin liittyvät haittavaikutukset voivat mer- kittävästi heikentää sairastuneen elämänlaatua $(14,15)$.

Eturauhassyövän tavallisimpia hoitokeinoja ovat eturauhasen poistoleikkaus, ulkoinen sädehoito, lyhytetäisyyksinen sädehoito ja hormonihoito. Leikkaushoidon mahdollisia haittavaikutuksia ovat virtsanpidätysongelmat ja erektiovaikeudet, sädehoidosta voi aiheutua edellisten lisäksi suolisto-oireita. Hormonihoidon haittoja ovat muun muassa seksuaalinen haluttomuus, erektiokyvyn menetys, kuumat aallot, anemia, lihasvoiman heikentyminen, painonnousu ja osteoporoosi. $(2,6$.) Paikallisen eturauhassyövän hoitovaihtoehtona on myös aktiivinen seuranta, sillä pienen riskin syövän ennuste on erittäin hyvä ilman hoitoa (16). Syöpädiagnoosin saamisen jälkeen on kuitenkin vaikeaa olla hoitamatta syöpää. Suuri osa miehistä, joilla todetaan PSA-testin seurauksena eturauhassyöpä, valitseekin radikaalihoidot (17).

Suomessa eturauhassyövän ilmaantuvuus kasvoi voimakkaasti 1990-luvulla, kun PSA-testin käyttö taudin varhaisessa diagnostiikassa yleistyi (18). Vaikka seulontaohjelmaa ei tällä hetkellä ole, PSA-testi on laajasti käytössä työterveyshuollossa, yksityisellä sektorilla ja perusterveydenhuollossa, ja tauti todetaan usein juuri PSA-mittauksen seurauksena ennen oireiden ilmenemistä. Tätä on pidetty ongelmallisena, sillä suositusten mukaan seulontatyyppistä testausta ei tulisi tehdä terveydenhuollossa, jos testimenetelmä ei täytä joukkoseulonnan kriteerejä (3, 19.) Organisoimattomassa seulonnassa ylidiagnostiikkaa esiintyy enemmän ja vaikutus eturauhassyöpäkuolleisuuteen on vähäinen tai sitä ei ole lainkaan (20). Useissa maissa on suositeltu, että miesten pitäisi saada tietoa PSA-mittausten hyödyistä ja haitoista ennen testin tekemistä eikä testiä tulisi tehdä ilman potilaan tietoista suostumusta (2). Suomalaisen Käypä hoito -suosituksen mukaan PSA-mittausta ei tule kieltää miehiltä, jotka epäilevät sairastavansa eturauhassyöpää eikä miehiltä, joilla on virtsaamisoireita, mutta ennen PSA-testin tekemistä potilaalle pitäisi kertoa testin mahdolliset seuraukset (6). Tällä hetkellä Suomessa on käynnissä seulontatutkimus, jonka tarkoituksena on selvittää, voidaanko ylidiagnostiikkaa vähentää uudenlaisella kolmiportaisella seulontaprotokollalla, mutta tuloksia saadaan aikaisintaan kymmenen vuoden kuluttua (21). 
Vaikka eturauhassyövän joukkoseulontaa tai oireettomien miesten rutiininomaista diagnostista testausta ei suositella, miesten on kansainvälisissä tutkimuksissa havaittu suhtautuvan myönteisesti PSA-mittauksiin ja seulontaan (22-24). Suomessa väestön tai potilaiden suhtautumista eturauhassyövän seulontaan ei ole juuri tutkittu. Vaikuttaisi siltä, että myös Suomessa suhtautuminen on hyväksyvä, sillä seulonnan vaikuttavuutta kartoittaneisiin tutkimuksiin on osallistunut noin $70 \%$ kutsutuista $(25,26)$. Suomessakin on pohdittu seulontaohjelman käynnistämistä ja aihe on ollut säännöllisesti julkisen keskustelun kohteena (27). Keskustelua on käyty myös eturauhassyöpäpotilaiden järjestöissä ja potilaille suunnatuissa lehdissä (28). Tietyt potilasjärjestöt (29) ja tukihenkilötoiminnassa mukana olevat miehet (30) ovat julkisuudessa kannattaneet nykyistä laajempaa seulontaa ja puolustaneet PSA-mittausten saatavuutta.

Eturauhassyöpään sairastuneilla on tyypillisesti ollut tärkeä rooli seulontaa koskevassa yhteiskunnallisessa keskustelussa. Aiempien tutkimusten $(31,32)$ mukaan keskusteluilla seulonnan haitoista tai ylimääräisistä hoidoista ei toistaiseksi näytä olleen suurta vaikutusta eturauhassyöpäpotilaiden seulontanäkemyksiin. Eturauhassyöpäpotilaiden on havaittu suhtautuvan hyvin myönteisesti PSA-seulontaan, ja vain harvat ovat ilmoittaneet katuneensa heille tehtyä PSA-mittausta. Potilaat ovat myös toivoneet, että tietoisuus eturauhassyövästä ja seulonnasta lisääntyisi.

Tässä artikkelissa tarkastellaan paikallista eturauhassyöpää sairastavien miesten näkemyksiä eturauhassyövän seulonnasta. Analyysin kohteena on se, miten eturauhassyöpään sairastuneet miehet perustelevat seulonnan tarpeellisuutta ja kuvaavat seulonnan hyötyjä ja haittoja.

\section{AINEISTO JA MENETELMÄT}

Tutkimuksen aineisto koostuu paikallista eturauhassyöpää sairastavien miesten ( $\mathrm{N}=28)$ yksilöhaastatteluista, jotka tehtiin vuosina 2012-2014. Haastattelut liittyivät laajempaan tutkimushankkeeseen, jossa tarkasteltiin mm. paikallisen eturauhassyövän hoitopäätöksiin liittyviä prosesseja, radikaalihoitojen jälkeistä elämänlaatua ja vertaistukitoimintaa. Haastatelluilta tiedusteltiin myös heidän näkemyksiään eturauhassyövän väestötason seulonnasta ja sen tarpeellisuudesta. Haastattelut olivat muodoltaan puolistrukturoi- tuja teemahaastatteluja. Tutkimusryhmä oli laatinut haastatteluja varten teemarungon, mutta kysymysten tarkoituksena oli lähinnä johdattaa haastateltavia kuvaamaan käsiteltävää aihetta. Tutkimusryhmään kuuluva jatko-opiskelija ja post doc -tutkija toteuttivat haastattelut. Haastateltavat saivat tietoa tutkimuksesta ja allekirjoittivat suostumuslomakkeen ennen haastattelua. Haastattelut tallennettiin tutkittavien tietoisella suostumuksella ja litteroitiin sen jälkeen tekstiksi. Yliopistollisen sairaalan erityisvastuualueen alueellinen eettinen toimikunta oli antanut tutkimussuunnitelmasta puoltavan lausunnon.

Haastateltavat rekrytoitiin yliopistollisen sairaalan potilastietokannasta (23 henkilöä), paikallisen Syöpäyhdistyksen kautta (4 henkilöä) sekä eturauhassyöpäpotilaille tarkoitetussa lehdessä julkaistun lehti-ilmoituksen avulla (1 henkilö). Haastateltavilla oli diagnosoitu PSA-mittauksen ja eturauhasesta otettujen koepalojen seurauksena paikallinen varhaisvaiheen syöpä, joka ei ollut aiheuttanut oireita ennen taudin toteamista. Tällaisen syövän hoitomuotoina käytetään aktiivista seurantaa, eturauhasen poistoleikkausta tai sädehoitoa. Suurimmalla osalla haastateltavista hoitomuotona oli ollut leikkaustai sädehoito, joista oli aiheutunut sivuvaikutuksia, kuten erektio- tai virtsanpidätysongelmia. Haastateltavista neljä oli aktiiviseurannassa. Erilaisista rekrytointitavoista johtuen haastateltavien miesten diagnooseista oli kulunut aikaa 315 vuotta, yleisimmin kuitenkin noin 4 vuotta. Haastateltavat olivat iältään 50-78-vuotiaita. Osa haastateltavista oli yhä työelämässä ja osa oli siirtynyt eläkkeelle. Haastateltavat edustivat useita ammattiryhmiä, ja heidän koulutustaustansa vaihteli.

Aineiston analyysivaiheessa huomio kiinnittyi aluksi siihen, että haastateltavat suhtautuivat nykyistä laajempaan seulontaan lähes yksimielisen myönteisesti. Monet olivat tietoisia siitä, että seulontaan liittyy haittoja, mutta siitä huolimatta he olivat seulonnan käynnistämisen kannalla. Siksi analyysissa keskityttiin argumentteihin, joilla miehet perustelivat seulonnan tarpeellisuutta sekä tapoihin, joilla esitetyt argumentit pyrittiin saamaan vakuuttaviksi ja kannatettaviksi. Analyysimenetelmänä käytettiin diskurssianalyysia. Diskurssianalyysissa tarkastelun keskiössä ovat merkitysten tuottamisen tavat ja argumentointia tarkastellaan kielellisinä tekoina ja sosiaalisena 
toimintana, tietyn position ottamisena julkisessa keskustelussa $(33,34)$. Analyysissa keskityttiin esitettyjen argumenttien lisäksi niihin diskursiivisiin strategioihin, joilla miehet perustelivat kantaansa väestötasoiseen seulontaan. Artikkelissa käytetyissä aineisto-otteissa kirjaimella K tarkoitetaan kysyjää ja kirjaimella V vastaajaa. Aineisto-otteita on lyhennetty luettavuuden parantamiseksi.

\section{TULOKSET}

Suurin osa haastateltavista suhtautui myönteisesti nykyistä laajempaan PSA-seulontaan. 28:sta miehestä 22 kannatti valtakunnallisen seulontaohjelman käynnistämistä. Vain kaksi miestä oli sitä mieltä, ettei eturauhassyöpää pitäisi seuloa väestötasolla. Miehistä neljä ei ilmaissut selkeää kantaa seulontakysymykseen tai oli epävarma asiasta. Lisäksi monet miehet kertoivat kannustaneensa tuntemiaan miehiä PSA-mittauksiin.

Noin puolet haastateltavista ei maininnut lainkaan seulonnan haittoja tai pohtinut, miksi seulontaohjelmaa ei tällä hetkellä ole, vaikka haastattelija toi usein esiin aiheen kiistanalaisuuden mainitsemalla, että aiheesta käydään keskustelua puolesta ja vastaan. Sen sijaan monet esittivät näkemyksensä varmasti ja kyseenalaistamattomasti. Toisaalta myös monet miehet, jotka toivat esiin seulonnan haittoja, kuten testin epäluotettavuuden, ylidiagnostiikan ja yksittäistapauksissa tarpeettomat hoidot, puolustivat voimakkaasti seulontaa ja olivat sitä mieltä, että seulontaan tulisi kaikesta huolimatta ryhtyä.

Seulonnan tarpeellisuutta perusteltiin useimmin argumenteilla, jotka liittyvät varhaisen diagnostiikan hyötyihin - kuten kustannusten säästymiseen, parempiin hoitomahdollisuuksiin ja kuolleisuuden vähentämiseen - tai miesten oikeuksiin ja sukupuolten tasa-arvoon. Monet miehet sekoittivat seulonnan ja niin kutsutun opportunistisen PSA-testauksen. Seulonnan tarpeellisuuden rinnalla haastateltavat korostivat omaehtoisen PSA-testauksen tärkeyttä ja miesten vastuuta terveydestään. Perustelut liittyivät vahvasti lääketieteessä ja terveydenhuollossa hallitsevaan prevention diskurssiin, jossa yhdistyvät terveyteen liittyvien riskitekijöiden tunnistaminen, muuttaminen ja moraalinen velvoite huolehtia terveydestä, sekä miesten terveyden diskurssiin, jossa miesten terveys kuvataan uhattuna ja sivuutettuna (35).

\section{SEULONNALLA SÄÄSTÖÄ YHTEISKUNNALLE}

Useat haastateltavat toivat esiin sen, että eturauhassyöpää voi seuloa yksinkertaisella verinäytteellä, joka on rutiinitoimenpide terveydenhuollossa. Vain yksi haastateltavista mainitsi koepalojen ottamisen seulonnan yhteydessä. Näin monet rajasivat seulontakysymyksen koskemaan vain itse testimenetelmää eivätkä pohtineet jatkodiagnostiikan tai mahdollisesti todettavan syövän potilaalle aiheuttamia haittoja. He kiistivät seulonnan haitat toteamalla esimerkiksi, ettei verikokeen ottamisesta aiheudu mitään pahaa.

PSA-seulonta esitettiinkin usein harmittomana ja edullisena tapana todeta eturauhassyöpä riittävän varhaisessa vaiheessa. Seulonnasta puhuttaessa kustannuksiin viitattiin kahdella tavalla. Yhtäältä tuotiin esille se, ettei esteitä seulonnan käynnistämiselle ole, sillä seulontamenetelmä on olemassa ja kyseessä on edullinen toimenpide. Toisaalta seulonnan kuvattiin vähentävän terveydenhuollon kustannuksia tai tuovan varhaisen diagnostiikan ansiosta "säästö̈̈ koko ybteiskunnalle". Seuraavassa aineisto-otteessa haastateltava ei mainitse, mitä seulonnalla tavoitellaan tai mitä hyötyjä siitä voisi olla, mutta korostaa seulonnan kustannusten pienuutta ja testimenetelmän helppoutta.

K: Mitäs sä muuten ajattelet seulonnoista? Kun eturauhassyövästä ei vielä seulontoja järjestetä väestötasolla niin ku rintasyövästä esimerkiks, niin pitäskö kaikilla miehillä olla pakollinen PSA-testi viiskymppisenä tai jotain?

V: Ehdottomasti, mä oon sitä mieltä että viis kymppiä ja sen jälkeen esimerkiks viiden vuoden välein. PSA-verikoe on niin yksinkertanen ottaa, eikä niin kauhiasti maksa. Aivan ehdottomasti. Se on niin simppeli juttu. Jos se ois pirun kallis tutkimus joka aiheuttaa suorastaan kansakunnan vararikkoon menon että kaikki tutkitaan niin se ois toinen juttu. Mutta nyt puhutaan niin, niin niin äärimmäisen pienistä kustannuksista että aivan pidän ehdottomana että kyllä pitäs.

Talouspuhe kietoutui vahvasti prevention hyötyjä painottavaan jäsennystapaan. Miehet vetosivat varhaisen diagnostiikan ansiosta säästyviin kustannuksiin ja vertasivat edullista PSA-testiä pitkälle edenneiden syöpien hoitokuluihin. Talous- 
puheelle tyypillistä oli se, että seulonta esitettiin eturauhassyövän riskiryhmien edun sijaan terveydenhuoltojärjestelmän ja kansantalouden etuna. Vaikka haastateltavat olivat eturauhassyöpään sairastuneita miehiä, joiden syöpä oli havaittu kohonneen PSA-pitoisuuden seurauksena, monet etäännyttivät väitteensä omista intresseistään vetoamalla yhteiskunnalliseen hyötyyn, kuten haastateltava seuraavassa aineisto-otteessa.

V: [P]itäis mun mielestä kyllä saada menetelmät sellaseksi jolla pystytään kontrolloimaan ja kattomaan, kuka vaatii sen hoidon ja kuka ei. Se ois mielestäni erittäin tärkeä saada käynnistettyä tämä [seulontaohjelma]. Koska maksaahan se yhteiskunnalle vielä enemmän sitte kun joudutaan [hoitamaan], että ei nää kontrollit voi olla kun murto-osa siitä. Vaikka siitä tulis tietynmoinen piikki leikkauksis tai sädehoidoissa, niin se on kumminki ohimenevä, parin kolmen vuoden periodissa, jonka jälkeen se tasaantuis. Ja se olis sitte tavallaan hallinnas, sama ku rintasyövän kohdallaki esimerkiks.

K: Eli pitäis löytää semmonen keino, millä pystyttäis erottelemaan syöpätyypistä semmoset, mitkä tulee pysymäänkin kilttinä ja ei tuu aiheuttamaan ongelmia? Niistä mitkä jossain vaiheessa lähtevät leviämään tai ärhäköityvät?

V: Kyllä. Koska joku tyyppi saattaa jopa viikkojen sisällä mennä siihen pisteeseen että lähettää jo etäpesäkkeitä tai laajenee että sitä on hyvin vaikea enää hoitaa. Ja sitte ne hoidot ainaki on hyvin kalliita. Sillä voitais välttää se ja jos tällaseen ikinä on mahdollisuus, niin kyllä näkisin [sen] erittäin tärkeänä, saada kontrolli pelaamaan. Koska viime kädes mä näkisin että se on säästöä koko yhteiskunnalle.

Edellisessä otteessa haastateltava tuo esiin sen, ettei kaikkia syöpiä tarvitsisi hoitaa, vaan pitäisi kehittää luotettavampi seulontamenetelmä, joka erottaisi aggressiiviset syövät hitaasti etenevistä syövistä. Tämä oli aineistossa poikkeuksellista. Haastateltava viittaa seulonnan seurauksena kasvaviin eturauhassyövän hoitokustannuksiin ohimenevänä, myöhemmin tasaantuvana piikkinä leikkauksissa ja sädehoidoissa, mutta suhteuttaa tilapäisen kustannusten kasvun nopeasti etene- vien syöpien hyvin kalliisiin hoitokustannuksiin. Rajaamalla asia kustannuskysymykseksi tarkastelun ulkopuolelle jää suurin osa niistä asioista, joiden perusteella seulontaohjelman käynnistämisestä päätetään. Sitä voidaan pitää myös tapana kiistää seulonnan haitat. Taloudellisten näkökohtien lisäksi haastateltavat korostivat seulonnan hyötyjä potilaille ja kuvasivat seulontaa tehokkaana menetelmänä vähentää eturauhassyöpäkuolleisuutta.

\section{SEULONTA VÄHENTÄÄ KUOLLEISUUTTA}

Eturauhassyöpä on hyväennusteinen syöpä, ja viiden vuoden kuluttua diagnoosista elossa on $93 \%$ potilaista (1). Merkittävä osa PSA-testauksen seurauksena todetuista eturauhassyövistä on paikallisia pienen riskin syöpiä, jotka eivät välttämättä vaikuta elinaikaan. Paikallisen eturauhassyövän hitaasti etenevästä luonteesta huolimatta monet viittasivat syöpään arvaamattomasti etenevänä, vakavana tautina, joka voi hoitamattomana levitä nopeasti. Taudin varhaisen toteamisen kuvattiin vähentävän hoitojen tarvetta, hoidoista aiheutuvia sivuvaikutuksia ja pidemmälle etenevien syöpien määrää sekä mahdollistavan hoidot ennen kuin on liian myöhäistä. Seulonnasta puhuessaan haastateltavat puolustivat usein nimenomaan syöpien varhaisen hoitamisen tarpeellisuutta. Jotkut miehet sekoittivat varhaisen diagnostiikan preventioon ja kuvasivat seulontaa ennakkohuoltona, syövän ennaltaehkäisynä tai keinona todeta syöpä etukäteen.

Haastateltavat kertoivat anekdootteja syöpään kuolleista tuttavistaan, joiden syöpä oli havaittu liian myöhään. Seulontamenetelmästä puhuessaan haastateltavat kuvasivat nimenomaan eturauhassyövän seulontaa ja PSA-testiä, kuten edellä on käynyt ilmi. Kuolleisuuden vähentämisestä puhuessaan perustelut liittyivät myös muihin syöpiin ja laajemmin kulttuurisiin käsityksiin syövästä tappavana tautina - vaikka syöpien vakavuus ja ennuste vaihtelevat, syöpä yhdistetään yleisesti kärsimykseen ja kuolemaan (12).

K: Mikä sun kanta on näihin seulontoihin? Pitäskö niitä järjestää ihan väestötasolla?

V: Kyllähän se hyvä on että, mitä varhasemmassa vaiheessa löytyy, niin sen parempihan se tietenkin on. Niin kun äitimuorista justiin kattelin että sit kun se lähti niin se meni sitten 
kovaa kyytiä ja se oli jo pitkällä siinä vaiheessa ku se löydettiin.

Kertoessaan vatsasyöpään kuolleesta äidistään haastateltava kuvaa nähneensä omin silmin, kuinka kovaa vauhtia syöpä etenee, jos sille antaa mahdollisuuden. Käyttämällä äidin kohtaloa perusteluna seulonnan tarpeellisuudelle siirrytään eturauhassyövän kontekstista käsittelemään syöpää eräänlaisena kuoleman synonyymina, yleistettynä tappavana tautina (ks. 36, 37), joka tulisi pysäyttää varhaisessa vaiheessa.

Syöpä siis esitettiin nopeasti etenevänä tautina, mutta varhaisen diagnostiikan ansiosta sen katsottiin olevan parannettavissa. Miehet eivät tuoneet esiin sellaista mahdollisuutta, että joskus syöpä voi edetä niin nopeasti, ettei seulonnasta olisi apua. Aineistossa huomio kiinnittyi siihen, että miehet olivat haluttomia jatkamaan keskustelua seulonnan haitoista. Kun puhe kääntyi PSAtestin epäluotettavuuteen tai ylidiagnostiikkaan, miehet turvautuivat usein hyökkäävään retoriikkaan ja pyrkivät kumoamaan esiin tulleet ongelmat. Seulonnan haitat kiistettiin vetoamalla - usein eufemistisin tai metaforisin ilmauksin - kuolemaan.

V: [O]likohan sen helsinkiläisen urologin peruste justiin se että, siinä vois tulla sitä turhaa paljon. Mutta mikä sit on toinen vaihtoehto, niinkun tää mun koulukaverikin, joka nyt heinäkuussa haudattiin, niin jos se olis mennykin vähä aikasemmin [lääkäriin] ja se olis todettu, se ei ois ollukaan turhaa. Niin yhtä hyvin, mä en ois menny lääkäriin, ja nyt mua ei enää olis tässä istumassa. Koska ei mulla ollu mitään.. no ehkä ny pikkasen, sanotaan et kun mies täyttää sen 50 niin se virtsasuihku vähä heikkenee ja jotain tämmöstä tietysti, pientä, mut ei minkäänlaista semmosta oiretta, että olis ollu syytä epäillä sitä. Ja kun vielä lääkärikin sano että "mee ny sinne urologille, muttei sussa kyllä mitään syöpää oo". Niin jos olis ollu semmone vähä välinpitämättömämpi lääkäri, et olis ollu siinä omassa kannassaan, että ei oo syöpää että älä mee turhan takia. Niin sillon olis ollu justiin tää, että hetken päästä se olis ollu sitte myöhästä.

Edellisessä aineisto-otteessa haastateltava kertoo ensin koulukaveristaan, joka on kuollut eturau- hassyöpään ja vertaa tätä toisena vaihtoehtona ylidiagnostiikalle. Hän toistaa vertauksen kuvaamalla omakohtaista kokemustaan eturauhassyöpään sairastumisesta. Haastateltava korostaa syövän oireettomuutta ja arvaamattomuutta (ei minkäänlaista semmosta oiretta) ja käyttää suoraa lainausta lääkärin puheesta ("mee ny sinne urologille, muttei sussa kyllä mitään syöpää oo”) argumenttiensa tueksi. Syntyy vaikutelma, että tämä "toinen vaibtoehto" - ettei syöpää olisi havaittu tarpeeksi ajoissa - oli hyvin lähellä toteutua. Otteessa huomio kiinnittyi myös siihen, että tarpeettomien tutkimusten välttäminen esitetään lääkärin välinpitämättömyytenä. Kuvaamalla muunlaisia lääkäreitä välinpitämättömiksi rakentuu kuva potilaitaan laiminlyövistä lääkäreistä, joiden toiminnan kritisoiminen on oikeutettua.

Seulonnan taloudellisista hyödyistä puhuessaan haastateltavat kuvasivat seulontaa kustannuskysymyksenä ja vetosivat seulonnan yhteiskunnallisiin vaikutuksiin. Kuolleisuuden vähentämisestä puhuessaan haastateltavat kuvasivat seulonnan hyötyjä potilaille. Omien intressien etäännyttämisen sijaan monet lausuivat väitteensä syöpäpotilaan positiosta ja viittasivat omaan kokemukseensa kuoleman välttämisestä. Miehet toivat esiin kiitollisuuden siitä, että heidän syöpänsä on löydetty riittävän ajoissa, ja ylidiagnostiikan katsottiin olevan jossakin muualla. Seuraavaksi tarkastellaan sitä, kuinka seulontaa ja PSA-testausta kuvattiin miesten terveyteen liittyvänä kysymyksenä - miesten oikeutena ja velvollisuutena.

\section{SEULONTA MIESTEN OIKEUTENA JA VELVOLLISUUTENA}

Miesten vähäisempi terveyspalvelujen käyttö on miesten elintapojen lisäksi yksi niistä tekijöistä, joiden vuoksi miessukupuoli ja erityisesti niin kutsuttu hegemoninen maskuliinisuus on käsitetty terveysriskinä. "Lääkäriä välttelevä suomalainen mies" on kulttuurisesti jaettu käsitys ja osa laajasti tunnistettua suomalaisen maskuliinisuuden myyttiä. (38.) Seulonnan ja PSA-testauksen tarpeellisuudesta puhuessaan miehet viittasivat lääkäriä kartteleviin miehiin, jotka eivät hakeudu PSA-mittauksiin. Seulonnasta puhuttiin yhtäältä miesten oikeutena ja terveyspoliittisena keinona edistää miesten terveyttä, toisaalta miesten velvollisuutena edistää terveyttään. Miesten terveyden kuvattiin olevan uhattuna miehiä koskevan oireettoman taudin vuoksi, koska lääkärit ja ter- 
veydenhuoltojärjestelmä eivät toimi niin kuin pitäisi. Toisaalta miesten välinpitämättömyyden ja tietämättömyyden kuvattiin vaarantavan heidän terveytensä. Miehet esitettiin siis kahdella tapaa riskiryhmänä.

Muutamat miehet arvostelivat voimakkaasti PSA-testauksen rajoittamista ja puolustivat miesten oikeutta tietoon. Seuraavassa aineisto-otteessa haastateltava ottaa seulontakysymyksen yhteydessä esiin sen, ettei hänen lääkärinsä ollut suostunut antamaan lähetettä PSA-mittaukseen toistuvista pyynnöistä huolimatta. Lopulta hän oli päässyt testiin mainittuaan asiasta toiselle lääkärille. Haastateltava pyrkii kyseenalaistamaan läkäkrin toiminnan korostamalla, että kyse on tiedosta, johon hän itse ei voi suhtautua välinpitämättömästi, mutta jolla lääkäri ei ”mitään tee”. Vaatimalla avoimuutta hän kuvaa lääkärin toimintaa pyrkimyksenä rajoittaa tiedon saantia tai salata potilailta heitä koskevaa tietoa.

K: Kun paljon puhutaan näistä seulonnoista väestötasolla, niin mikä teidän kanta on, pitäiskö näitä PSA-arvoja ottaa tai seuloa ihan väestötasolla?

V: Kyllä ehdottomasti. Mua niin suututtaa tämä ensimmäinen lääkäri joka sano että ne voi paljastaa meille sellaista mitä meidän ei tarvitse edes tietää. Ja kun minä ajattelen asiaa, kun lääkäri sanoo mulle että meidän ei tarvitse edes tietää. Mutta se täytyy kääntää monikkomuodosta yksikkömuotoon. Minun tarvitsee tietää. Eihän hän sillä tiedolla mitään tee, mutta minä teen. Tää on niitä, tää on niitä että avoimuutta.

Testimenetelmän epäluotettavuuden sijaan miehet kuvasivat ongelmallisena testin riittämättömän saatavuuden. Tällaiset kuvaukset synnyttivät vaikutelman siitä, ettei terveydenhuoltoon voi luottaa, vaan syövän toteaminen on miesten omissa käsissä. Osa miehistä perusteli seulonnan tarpeellisuutta myös sukupuolten tasa-arvolla tuomalla esille sen, että naisille järjestetään rintasyöpäseulontoja, mutta miesten yleisimmän syövän toteamiseksi vastaavaa seulontaohjelmaa ei ole järjestetty. Seuraavassa aineisto-otteessa haastateltava huomauttaa, että eturauhassyövän ja rintasyövän vuosittainen ilmaantuvuus on yhtä suurta ja vahvistaa tilastoihin viittaamalla vaikutelmaa siitä, ettei tasa-arvo tällä hetkellä toteudu.

K: Jos miettii eturauhassyövän seulontoja, kun niistähän paljon keskustellaan puolesta ja vastaan, että pitäiskö sitä ulottaa koko väestötasolle. Niin mikä sun kanta on siihen asiaan, pitäskö ne seulonnat olla?

V: Pitäisin hyvin tärkeänä. Siitä on keskusteltu tästä asiasta. Siinähän on näitä näkökantoja, että sehän ois ennen kaikkeaki hyvin kallis toimenpide tehdä koko väestölle. Mutta jos vertaa nyt vaikka rintasyöpäseulontoihin jota nyt vuosittain, eikö se oo noin neljän ja puolen tuhannen paikkeilla, ja se on hyvin saman verran eturauhassyöpätapauksia? Muistaakseni nämä, tilastot niin.

Tasa-arvoon vetoaminen olikin aineistossa yksi niistä retorisista strategioista, joilla kiistettiin seulonnan haitat. Vaikka eturauhassyövän seulonnan käynnistämisen esteenä ovat olleet seulontamenetelmään liittyvät ongelmat, naisten seulontoihin vetoaminen synnyttää vaikutelman siitä, ettei miesten terveyteen panosteta samalla tavalla kuin naisten terveyteen. Nimeämällä seulonnan puuttuminen tasa-arvo-ongelmaksi keskustelu siirtyy seulonnan hyötyjen ja haittojen tarkastelusta siihen, kenellä on oikeus tai mahdollisuus päästä seulontaan.

Analyysissa huomio kiinnittyi myös valistavaan, moralisoivaan ja velvoittavaan puhetapaan, jolla PSA-mittausten tärkeyttä korostettiin. Sen lisäksi, että miehet puolustivat voimakkaasti seulonnan tarpeellisuutta, lähes puolet haastateltavista kertoi kehottaneensa tuntemiaan miehiä PSA-testeihin. Seuraavassa aineisto-otteessa haastateltava ottaa tämän esille, kun häneltä kysytään näkemystä seulonnasta. Hän ei perustele seulonnan tarpeellisuutta tai mainitse sen hyötyjä, mutta korostaa, että PSA-pitoisuutta on syytä seurata aina, kun verinäytteitä otetaan ja alleviivaa sitä, että hän on itse säännönmukaisesti muistanut neuvoa muita miehiä tässä asiassa.

K: [M]itä sä aattelet eturauhassyövän seulonnasta että kun sitä PSA-testiä tehdään että pitäskö semmosta seulontaa olla samal lailla kun naisille rintasyövässä, esimerkiksi. 
V: Kyllä mä oon sitä mieltä ja mä oon aina sanonu kaikille tuttaville, ikäsilleni ja tommosille mä sanon että aina kun meette terveyskeskuk-, verikokeeseen yleensä niin pyydätte sen PSA:n siihen samaan. Kyllä se on ihan oleellinen asia, et sitä seurattas. Aina kun vaikka minkä muun asian takia otetaan verikoe jossain, niin pyytäs sen PSA:n siinä samalla, jos ei sitä oo kerran otettu aikoihin. Kyllä mä oon aina, aina kun tulee vähän juttua näistä niin mä oon aina välittäny sitä tietoa että muistakaa pyytää se.

Muiden miesten kannustaminen PSA-testeihin voi olla eturauhassyöpäpotilaille tapa puhua sairaudestaan. Monet mainitsivat asian siinä yhteydessä, kun haastattelija kysyi, ovatko he keskustelleet eturauhassyövästään muiden kanssa. Kuvaamalla sitä, kuinka he ovat levittäneet tietoa PSA-testistä haastateltavat myös korostivat omaa aktiivisuuttaan ja vastuullisuuttaan sekä asemoivat itsensä asiantuntijoiksi suhteessa muihin miehiin.

Seuraavassa aineisto-otteessa haastattelija on aiemmin yrittänyt aloittaa keskustelua seulonnan haitoista. Haastateltava on puolustautunut voimakkaasti ja korostanut, että hän on tietoinen seulonnan haitoista, mutta seulonta pitäisi ehdottomasti aloittaa. Kun haastattelija viittaa siihen, että seulontalöydökset voisivat aiheuttaa ahdistusta, haastateltava alkaa kritisoida seulontamenetelmän puutteiden sijaan miehiä, jotka eivät "uskalla mennä lääkärin pubeille”.

K: Sekin on tietysti että eri ihmiset kokee sen eri tavalla että jotkuthan saattaa hyvinkin paljo ahdistua siitä asiasta jos sitten löytyykin jotakin.

V: Ihmettelen kun aikuiset raavaat miehet ei uskalla mennä lääkärin puheille.

K: Niin. Joo.

V: Pelkää piikkiä ja kaikkea tämmöstä. Isot miehet.

Haastateltava kiistää seulonnan haitat kääntämällä keskustelun seulonnan mahdollisista negatiivisista seurauksista seulontamenetelmään (pelkää piikkiä), mikä on tehokas keino saada kritiik- ki näyttämään oikeutetulta ja isojen, raavaiden, aikuisten miesten lääkärin pelko naurettavalta. Keskustelua esimerkiksi epänormaalin löydöksen aiheuttamasta ahdistuksesta, hoitopäätöksen tekemisestä tai hoidoista mahdollisesti aiheutuvista virtsa- ja erektio-ongelmista olisi tämän jälkeen erittäin vaikea jatkaa.

\section{POHDINTA}

Haastateltavat puolustivat vahvasti argumentoiden sekä seulonnan aloittamista että PSA-mittausten saatavuutta. Vain kaksi miestä oli sitä mieltä, ettei eturauhassyöpää pitäisi seuloa väestötasolla perustellen kantaansa sillä, että seulonta voisi heikentää miesten elämänlaatua. Jotkut haastateltavat mainitsivat, että suurelta osalta vanhemmista miehistä löytyisi harmiton eturauhassyöpä, jos PSA-testausta lisättäisiin. Sen sijaan miehet eivät juurikaan pohtineet, mitä tiedosta voi seurata potilaille. Kukaan haastateltavista ei maininnut sitä, että diagnoosin jälkeen täytyy tehdä päätös hoidosta, ettei hoidon hyödyllisyydestä ole aina varmuutta tai että hoidoista voi aiheutua esimerkiksi erektio- ja virtsanpidätysongelmia, vaikka suurimmalle osalle heistä hoidot olivat aiheuttaneet näitä sivuvaikutuksia. Miehet eivät myöskään maininneet kyseenalaistaneensa tai katuneensa heille tehtyjä PSA-mittauksia.

Seulonta näyttäytyi aineistossamme hyvin poliittisena asiana, jossa seulonnan etujen ja haittojen neutraalin pohdinnan sijasta haastateltavat puolustivat voimakkaasti kantojaan ja sivuuttivat monia omille näkemyksilleen vastakkaisia perusteluja. Analyysimme osoittaa, että suomalaiset miehet ovat omaksuneet terveyden edistämisen keskeisen teesin - prevention - osaksi terveysajatteluaan. Prevention hyödyt liitettiin vahvasti talousajatteluun, jossa seulonnan ansiosta saavutettavat säästöt yhteiskunnalle nähdään kiistämättöminä etuina. Pyrkimykset terveyden edistämiseen, yhteiskunnalliseen hyötyyn ja tasaarvoon ovat asioita, joiden varaan on helppoa rakentaa vahvoja argumentteja ja joihin haastateltavat vetosivat puolustaessaan mielipidettään seulonnan tarpeellisuudesta.

Sitä, että haastateltavat eivät juuri tuoneet esiin seulonnan vastaisia argumentteja, voidaan tulkita kahdella erilaisella tavalla. Seulonnan ympärillä käytävä keskustelu on ristiriitaista ja seulontaa koskeva tieto on vaikeasti hahmotettavaa, joten on mahdollista, että haastateltavien on 
hankalaa hahmottaa eri perustelujen keskinäisiä suhteita (39). Toisaalta suuri osa haastatelluista oli tietoisia siitä, että seulontaan liittyy myös haittoja. Asiaa voikin tulkita myös edunvalvonnan näkökulmasta niin, että haastatelluilla oli asiassa vahva oma kantansa, ja saadakseen tämän mielipiteen riittävän vakuuttavasti ilmaistuksi he tietoisesti jättivät tätä kantaa heikentävät näkökulmat huomioimatta.

Perustelut noudattavat suurelta osin tietynlaista edunvalvontapolitiikan logiikkaa, jossa seulontojen järjestäminen nähdään keinona lisätä tietoisuutta eturauhassyövästä ja puolustaa oman potilasryhmän asemaa terveyspolitiikan priorisoinneissa $(30,31)$. Edunvalvontaa tehdään suhteessa muihin potilasryhmiin, erityisesti naisiin, mutta vastapuolena kuvattiin terveydenhuoltojärjestelmää ja tämän edustajina lääkäreitä, jotka useissa kohdin esitettiin välinpitämättöminä ja potilaan etua ymmärtämättöminä. Haastateltavat asemoivat itsensä miesten terveyttä edistävinä aktivisteina, jotka ajavat yhteiskunnallisen tasa-arvon ohella rationaalista ja kustannustehokasta terveyspolitiikkaa.

Edellisten lisäksi on mahdollista, että haastattelemiemme miesten oma hoitohistoria vaikuttaa heidän tapaansa jäsentää seulonnan problematiikkaa. Haastateltavilla oli todettu paikallinen eturauhassyöpä, ja heille oli tarjottu aktiiviseurantaa ensisijaisena tai yhtenä mahdollisena hoitovaihtoehtona. Suurin osa heistä oli kuitenkin valinnut leikkaus- tai sädehoidon. Kyseessä voi olla tapa puolustaa ja rationalisoida omia hoitovalintoja $(32,36)$. Pohtiessaan kantaansa seulontaan he mahdollisesti suhteuttivat sen etuja ja haittoja erityisesti syövästä hengissä selviytymiseen, jolloin hoitojen sivuvaikutukset ja niiden vaikutukset elämänlaatuun jäävät toissijaisiksi (40).
Nykyisessä terveyspolitiikassa korostetaan potilaiden osallisuutta ja kokemustiedon merkitystä terveydenhuollon kehittämisessä (41). Kokemustiedolla on epäilemättä tärkeä osansa terveyspalveluiden suunnittelussa ja kehittämisessä, ja tästä näkökulmasta on tärkeää, että monet potilasryhmät ottavat aktiivisesti osaa terveydenhuollon suunnittelusta käytävään keskusteluun. Tutkimuksemme osoittaa, että eturauhassyöpää sairastavat miehet katsovat omien kokemustensa antavan heille legitiimin aseman terveyspoliittisten linjausten arvioinnissa. Potilaille syöpäseulonnat näyttäytyvät kuitenkin helposti nollasummapelin luonteisena edunvalvontana, jossa eri potilasryhmiä koskevat linjaukset suhteutuvat aina oman ryhmän voittoihin tai tappioihin. Vaikka sairauskokemuksiin perustuva tieto auttaa paremmin ymmärtämään potilaiden tarpeita, ja siten kehittämään palveluita, kokemustietoon usein sisältyvä edunvalvontanäkökulma rajoittaa sen käytettävyyttä seulontojen kaltaisista laajoista ja moniulotteisista asioista keskusteltaessa. Terveyspolitiikassa seulontojen hyödyt ja haitat on asetettava tiettyä potilasryhmää laajempaan kansanterveydelliseen yhteyteensä.

\section{RAHOITTAJAT:}

Tutkimuksessa käytetty aineisto on kerätty Pirkanmaan Syöpäyhdistyksen rahoittamassa tutkimushankkeessa Paikallisen eturauhassyövän hoidon ja hoitomuotojen valinnan psykososiaaliset ulottuvundet (QPro).

\section{KIRJOITTAJIEN KONTRIBUUTIOT:}

Pietilä ja Hakulinen suunnittelivat tutkimuksen asetelman. Ojala osallistui haastattelujen tekemiseen. Hakulinen analysoi aineiston. Hakulinen, Ojala ja Pietilä kirjoittivat artikkelikäsikirjoituksen.

\section{Hakulinen, A., Ojala, H., Pietilä, I. Promoting men's rights in the field of health policy: patients' argumentation for the usefulness of prostate cancer screenings. Sosiaalilääketieteellinen aikakauslehti - Journal of Social Medicine 2020: 57: 348-358.}

In recent years, there have been active discussions on the benefits and disadvantages of prostate cancer screening. While the PSA blood test is widely used in health care, population screening is not recommended as its harms are considered to outweigh the benefits. The harms associated with screening include over-diagnosis and unnec- essary treatments that can reduce men's quality of life. This study was aimed at exploring the views of men with prostate cancer on the necessity of screening. The study was based on semi-structured individual interviews conducted with 28 prostate cancer patients. The interviews were analysed using discourse analysis. 
The majority of the interviewees supported the establishment of a national screening programme and argued that PSA testing should be accessible for all men. The importance of screening was commonly justified with arguments related to the benefits of early diagnostics, such as cost saving and reduction of mortality. Additionally, screening was supported with justifications based on men's rights and gender equality. Our findings suggest that men who advocate screening are aware of the harms of screening. Screening was perceived as a way of promoting men's health.

Keywords: Health policy, men's health, prostate cancer screening, argumentation.

Saapunut 11.09.2019

Hyväksytty 07.05.2020

\section{LÄHTEET}

(1) Suomen syöpärekisteri 2019. Luettu 3.6.2019. www.syoparekisteri.fi

(2) EAU Guidelines: Prostate cancer, 2019. Luettu 3.6.2019. https://uroweb.org/guideline/prostatecancer/

(3) Malila N, Sarkeala T, Anttila A. Syöpäseulonnat. Julkaisussa: Seulonnat Suomessa 2014. Terveydenhuollon seulontojen nykytila ja tulevaisuuden näkymät. Sosiaali- ja terveysministeriön julkaisuja 2014:17. Helsinki: Sosiaali- ja terveysministeriö.

(4) Mäkelä M, Saalasti-Koskinen U, Haula T, ym. Seulontojen arviointi ja niistä päättäminen. Julkaisussa: Seulonnat Suomessa 2014. Terveydenhuollon seulontojen nykytila ja tulevaisuuden näkymät. Sosiaali- ja terveysministeriön julkaisuja 2014:17. Helsinki: Sosiaali- ja terveysministeriö.

(5) Anttila A, Heinävaara S, Sarkeala T. Syöpäseulonnat. Julkaisussa: Syöpä Suomessa. Syöpäjärjestöjen raportteja 2016. Luettu 31.5.2019. https://www.syopajarjestot.fi/ julkaisut/raportit/syopa-suomessa-2016/ syopaseulonnat/

(6) Eturauhassyöpä: Käypä hoito -suositus, 2014. Suomalaisen Lääkäriseuran Duodecimin ja Suomen Urologiyhdistys ry:n asettama työryhmä. Helsinki: Suomalainen Lääkäriseura Duodecim. Luettu 31.5.2019. https://www.kaypahoito.fi/hoi11060

(7) Buzzoni C, Auvinen A, Roobol M, ym. Metastatic prostate cancer incidence and prostate-specific antigen testing: new insights from the European randomized study of screening for prostate cancer. Eur Urol 2015;68:885-890.

doi: 10.1016/j.eururo.2015.02.042

(8) Schröder F, Hugosson J, Roobol M, ym. Screening and prostate cancer mortality: results of the European Randomised Study of Screening for Prostate Cancer (ERSPC) at 13 years of follow-up. Lancet 2014;384:2017-2035. doi: 10.1016/S0140-6736(14)60525-0

(9) Booth N, Rissanen P, Tammela T, ym. Costs of screening for prostate cancer: Evidence from the Finnish Randomised Study of Screening for Prostate Cancer after 20-year follow-up using register data. Eur J Cancer 2018;93:108-118. doi: 10.1016/j.ejca.2018.01.111
(10) Vasarainen H, Malmi H, Määttänen L, ym. Effects of prostate cancer screening on healthrelated quality of life: Results of the Finnish arm of the European randomized screening trial (ERSPC). Acta Oncol 2013;52:1615-1621. doi: 10.3109/0284186X.2013.802837

(11) Ilic D, Neuberger M, Djulbegovic M, ym. Screening for prostate cancer. Cochrane Database Syst Rev 2013;1:CD004720. doi: 10.1002/14651858.CD004720.pub3

(12) Klotz L. Cancer overdiagnosis and overtreatment. Curr Opin Urol 2012;22:203-209. doi: 10.1097/MOU.0b013e32835259aa

(13) Auvinen A, Moss S, Tammela T, ym. Absolute effect of prostate cancer screening: balance of benefits and harms by center within the European randomized study of prostate cancer screening. Clin Cancer Res 2016;22:243-249. doi: 10.1158/1078-0432.CCR-15-0941

(14) Heijnsdijk E, Wever E, Auvinen A, ym. Qualityof-life effects of prostate-specific antigen screening. New Engl J Med 2012;367:595-605. doi: 10.1056/NEJMoa1201637

(15) Lehto U-S, Tenhola H, Taari K, ym. Eturauhassyövän hoitojen haitat ja potilaiden tyytyväisyys. Lääkärilehti 2013;68:2997-3005.

(16) Klotz L. Prostate cancer overdiagnosis and overtreatment. Curr Opin Endocrinol Diabetes Obes 2013;20:204-209. doi: 10.1097/MED.0b013e328360332a

(17) Wilt T, Ahmed H. Prostate cancer screening and the management of clinically localized disease. BMJ 2013;346:f325. doi: $10.1136 / \mathrm{bmj} .\{325$

(18) Pukkala E, Sankila R, Rautalahti M. Syöpä Suomessa 2011. Syöpäjärjestöjen julkaisuja nro 82. Helsinki: Suomen syöpäyhdistys; 2011. Luettu 3.6.2019. https://s3-eu-west-1. amazonaws.com/frantic/syopa-jarjestot/SyopaSuomessa-2011.pdf

(19) Sauni R, Hakulinen-Viitanen T, Pelkonen M, ym. Terveystarkastukset. Julkaisussa: Seulonnat Suomessa 2014. Terveydenhuollon seulontojen nykytila ja tulevaisuuden näkymät. Sosiaali- ja terveysministeriön julkaisuja 2014:17. Helsinki: Sosiaali- ja terveysministeriö.

(20) Godtman R, Holmberg E, Lilja H, ym. Opportunistic testing versus organized prostate- 
specific antigen screening: Outcome after 18 years in the Göteborg randomized populationbased prostate cancer screening trial. Eur Urol 2015;68:354-360.

doi: 10.1016/j.eururo.2014.12.006

(21) Auvinen A, Mirtti T, Tammela T, ym. Uusi eturauhassyövän seulontatutkimus pyrkii parantamaan hyötyjen ja haittojen suhdetta. Duodecim 2018;134:1429-31.

(22) Howard K, Brenner A, Lewis C, ym. A comparison of US and Australian men's values and preferences for PSA screening. BMC Health Serv Res 2013;13:388.

doi: 10.1186/1472-6963-13-388

(23) Partin M, Lillie S, White K, ym. Similar perspectives on prostate cancer screening value and new guidelines across patient demographic and PSA level subgroups: A qualitative study. Health Expect 2017;20:779-787. doi: 10.1111/hex.12517

(24) Smith S, Birtwhistle R. Exploring patient perceptions of PSA screening for prostate cancer: Risks, effectiveness, and importance. Can Fam Physician 2012;58:502-507.

(25) Kilpeläinen T, Tammela T, Malila N, ym. Prostate cancer mortality in the Finnish randomized screening trial. J Natl Cancer Inst 2013;105:719-725. doi: 10.1093/jnci/djt038

(26) Malmi H, Ruutu M, Määttänen L, ym. Why do men opt out of prostate-cancer screening? Attitudes and perception among participants and non-participants of a screening trial. BJU Int 2010;106:472-477. doi: 10.1111/j.1464-410X.2010.09165.x

(27) Toimenpidealoite 53/2013. Luettu 3.6.2019. https://www.eduskunta.fi/FI/vaski/ EduskuntaAloite/Documents/tpa_53+2013.pdf

(28) Sarakorpi J. Kokeneen syöpätautilääkärin neuvo: Käykää miehet PSA-testissä. Suomen potilaslehti 2/2014, 16.

(29) Eturauhassyöpäpotilaiden tuki ry. Kannanotto: eturauhassyövän varhainen toteaminen saatava järjestetyksi. Luettu 3.6.2019. http://www.ersy.fi/psa.php

(30) Jones M, Pietilä I. Expertise, advocacy and activism - a qualitative study on the activities of prostate cancer peer support workers. Health (London) 2018. doi: 10.1177/1363459318785711

(31) Chapple A, Ziebland S, Shepperd S, ym. Why men with prostate cancer want wider access to prostate specific antigen testing: Qualitative study. BMJ 2002;325:737. doi: 10.1136/bmj.325.7367.737

(32) Orom H, Underwood W, Homish L, ym. Prostate cancer survivors' beliefs about screening and treatment decision-making experiences in an era of controversy. Psychooncology
2015;24:1073-1079.

doi: 10.1002/pon.3721

(33) Billig M. Arguing and thinking: A rhetorical approach to social psychology. Cambridge: Cambridge University Press; 1987.

(34) Jokinen A. Vakuuttelevan ja suostuttelevan retoriikan analysoiminen. Kirjassa: Jokinen A, Juhila K, Suoninen E. Diskurssianalyysi liikkeessä. Tampere: Vastapaino; 1999, 126-159.

(35) Petersen A, Lupton D. The new public health. Health and self in the age of risk. London: SAGE publications; 1996.

(36) Pietilä I, Ojala H, Helminen S, ym. Who has the guts to make this choice? Ideals of masculinity in men's justifications for their treatment decisions for localised prostate cancer. Int J Mens Health 2016;15:267-282.

(37) Pietilä I, Ojala H, Helminen S, ym. Eturauhassyövän tukihenkilö - vertainen vai asiantuntija? Sosiaalilääk aikak 2014;51:101112.

(38) Pietilä I. Between rocks and hard places. Ideological dilemmas in men's talk about health and gender. Acta Universitatis Tamperensis 1329. Tampere: Tampere University Press; 2008.

(39) Brett A, Ablin R. Prostate-cancer screening What the U.S. Preventive services task force left out. New Engl J Med 2011;365:1949-1951. doi: 10.1056/NEJMp1112191

(40) Ransohoff D, McNaughton Collins $\mathrm{M}$, Fowler F. Why is prostate cancer screening so common when the evidence is so uncertain? A system without negative feedback. Am J Med 2002;113:663-667. doi: 10.1016/S0002-9343(02)01235-4

(41) Jones M, Pietilä I. "The citizen is stepping into a new role" - policy interpretations of patient and public involvement. Health Soc Care Community 2018;26:e304-e311. doi: 10.1111/hsc. 12520

\section{Annastima HaKulinen \\ TtM, tutkija \\ Tampereen yliopisto \\ Yhteiskuntatieteiden tiedekunta, terveystieteet}

Hanna OJala

KT, dosentti, yliopistonlebtori

Tampereen yliopisto

Yhteiskuntatieteiden tiedekunta, sukupuolentutkimus

\author{
ILkKa Pietilä \\ FT, dosentti, apulaisprofessori \\ Helsingin yliopisto \\ Valtiotieteellinen tiedekunta
}

